\title{
LAADULLISEN TUTKIMUKSEN VAKUUTTAVUUDESTA
}

$\mathrm{T}$ loimituskunnan toiveesta saada Aikuiskasvatus-lehdestä keskustelevampaa otan nyt esille asian, joka on jo pidempään häirinnyt Aikuiskasvatus-lehteä, erityisesti sen referoituja artikkeleja, lukiessani. Olen pannut merkille laadullisiin menetelmiin ja aineistoihin perustuvissa artikkeleissa toistuvat selitykset valitun menetelmän, aineiston ja analyysin validiteetista. Melkeinpä jokaisesta parin viime vuoden ajalta selailemastani lehdestä saan lukea selitykset siitä, kuinka laadullisen tutkimuksen tulosten pohjana ollut aineisto on subjektiivista, valikoitunutta, määrällisesti vähäistä (esimerkiksi haastateltavien määrä) ja tietyssä tilanteessa tuotettua, jonka pohjalta lukijan kannattaa kriittisesti arvioida saatujen tulosten yleistettävyyttä.

Olen elänyt vahvasti siinä uskossa, että nykyisin oltaisiin jo päästy keskustelemaan kvantitatiivisin ja kvalitatiivisin lähestymisin tuotetusta tiedosta tasavertaisena ja suhteessa omiin konteksteihinsa. Näin ei kuitenkaan näytä olevan.
Subjektiivisuuden, valikoituneisuuden, määrällisen vähyyden ja tilanteeseen kiinnittymisen nostaminen tutkimuksen vakuuttavuuden kompastuskiviksi kielii mielestäni vahvasta kvantitatiivisesta koordinaatistosta. Vallalla näyttäisikin olevan, kuten Pertti Töttö kirjassaan "Pirullisen positivismin paluu. Laadullisen ja määrällisen tarkastelua" (Vastapainno 2000) toteaa, lähestymistavallinen kaksinaismoralismi, jossa päivänvalossa pidetään laadullista ja määrällistä tutkimusta toisiaan täydentävinä, mutta illan hämärissä huomaa toisen pitävän vankasti valtaa. Toisin sanoen pidetään areena vapaana molemmille orientaatioille, mutta julkiseksi, siis tieteelliseksi tekstiksi halutessaan merkitsee tämä toisen, tässä tapauksessa määrällisen, puhemaailmassa toimimista, siihen peilaamista ja sovittautumista.

Määrällisessä koordinaatistossa toimiminen kilpistyy julkiteksteissä 'lopuksi lienee paikallaan kiinnittää huomiota' -selittelyihin, jotka asettavat tekstit, siis tutkimukset ja niiden tulokset, san- 
gen huvittavaan valoon. Niistä piirteistä (subjektiivisuus, valikoituneisuus, määrän vähyys, kontekstisidonnaisuus), jotka antavat laadulliselle tutkimukselle lisäarvoa, tehdäänkin yhtäkkiä kompastuskiviä, joista ei päästä yli ja jotka mitätöivät juuri aiemmin (yleensä selittelyt ladataan viimeiseen kappaleeseen) artikkelissa esitettyjä tuloksia. Surullisinta lienee kuitenkin se, että kirjoittaja näin tehdessään ei tee hallaa vain omalle tutkimukselleen ja tutkijuudelleen, vaan mitä enimmässä määrin myös muille laadullisen tutkimuksen tekijöille. Toimimalla määrällisen koordinaatistossa kyseenalaistuu laadullista tutkimusta tekevien tutkijoiden ammattitaito, teoreettinen, metodologinen ja metodinen tietämys ja osaaminen. Samalla myös tullaan mitätöineeksi paitsi laadullisia aineistonhankinta- ja analyysimetodeja, myös niitä ihmiseen, tietoon, tietäjyyteen, valtaan ja eroihin liittyviä näkemyksiä, joihin laadullista tutkimusta tekevät ovat tahoillaan sitoutuneet. Ei myöskään sovi unohtaa, että määrällisessä koordinaatistossa toimiminen asettaa kyseenalaiseksi myös tutkimushenkilöiden kompetenssin kertoa ajatuksistaan, mielipiteistään ja kokemuksistaan suhteessa tutkittavaan ilmiöön.

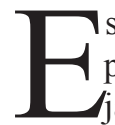

simerkkinä määrällisen koordinaatistossa puhumisesta voi käyttää vaikkapa Laitisen ja Nurmen artikkelia "Aktiiviseksi kansalaiseksi kasvaminen suomalaisten elämänkertojen valossa" (Aikuiskasvatus 2/2003), jossa kirjoittajat tekstinsä loppukaneetiksi toteavat tutkimuksensa vakuuttavuuden arvioinnin liittyvän pitkälti "haastateltavien valintaan, joka tapahtui tutkimuksen neuvoa antavan asiantuntijaryhmän esiin nostamista ehdokkaista. Näin ollen myös tutkimuksen validiteetti on pitkälti heidän 'kentän tuntemuksensa' varassa." Laitinen ja Nurmi tulevat näin sanoessaan sälyttäneeksi vastuun asiantuntijaryhmän jäsenille, jonka kokoonpanon he vieläpä muutamaa sivua aikaisemmin tekstissään nimeävät. Tutkijat kuitenkin itse tekivät haastattelupyynnöt etukäteen päätettyjen kriteerien (ikä-, sukupuoli ja konteksti) valossa asiantuntijaryhmän nimeämiltä ehdokkailta. Ei myöskään sovi unohtaa, että haastateltavat, ainakin toivottavasti, osallistuivat tutkimukseen vapaaehtoisesti ja siksi myös heillä on vaikutuksensa ja vastuunsa tutkimusaineistoon ja sitä kautta tuloksiin.

Laitinen ja Nurmi jatkavat edelleen: "(v)ain jos oletamme, että haastatelluiksi valikoituneet henkilöt edustavat suomalaisen aktiivisen kansalai- suuden ydintä, tutkimus on voinut kertoa oleellisia seikkoja suomalaisesta aktiivisesta kansalaisuudesta ja sen oppimisesta." Näin sanoessaan kirjoittajat tulevat kyseenalaistaneeksi paitsi oman tutkimuksensa, sen tulokset ja itsensä tutkijoina, myös asiantuntijaryhmän asiantuntemuksen sekä haastattelemansa aktiiviset kansalaiset.

Ihmettelen, miksi hyviä tutkimustuloksia esitelleen artikkelin lopuksi pitää lähteä selittelylinjalle. Jos tutkija valitsee laadullisen lähestymisen, merkitsee se eittämättä määrällisesti pientä tutkittavajoukkoa, rajatussa kontekstissa tapahtuvaa aineiston hankintaa ja subjektiivisia kertomuksia. Tutkimuksen tekeminen on alusta loppuun täynnä valintoja, jotka mahdollistavat, mutta myös rajaavat jotain ulkopuolelle. Toisin sanoen tietyllä asenteella tuotettu aineisto on valinta, joka rajaa myös analysointi- ja esittämismahdollisuuksia. Miksi siis lähteä kääntämään kesken kaiken kelkkaa, rakentaa itselle tietoisesti kompastuskiviä, kun voisi mennä niiden yli, arvioida niitä kriittisesti ja seisoa valintojensa ja tulkintojensa takana rinta rottingilla.

Tässä, laadullisen tutkimuksen tekijän näkökulmasta katsottuna, huvittaviakin piirteitä saavassa ilmiössä on eittämättä kyse kiistelystä todellisuudesta ja totuudesta. Mutta kyse on pitkälti myös tiedosta ja vallasta. Toisin sanoen siitä, mikä valta määrittelee sen, kuka voi tietää mitä, ja miten tutkija tietää sen, mitä hän tietää? Miten valta ilmenee, miten, missä ja mihin eroja tuotetaan ja rakennetaan ja kenen ymmärrys eroista saa milloinkin olla totuutena vallalla ja miksi? Mikä on siis todellisuuden, totuuden, tiedon ja vallan välinen yhteys ja miten tuo yhteys on mistäkin lähestymistavasta käsin vakuutettavissa?

Jos tutkija lähestymistavastaan riippumatta tiedostaa, tunnistaa ja tunnustaa omat sitoumuksensa ja lähtökohtansa tutkijana, onnistuu hän irrottautumaan niistä siinä mielessä, että hän asettaa väitteensä oikeaan yhteyteen. Kyse on siis pyrkimyksestä ymmärtää sitä, miten oma tutkijapositio on tuotettu ja miten sitä itse tuottaa ja uusintaa, mitä positio mahdollistaa tiedon tuottajana tai toisaalta, mitä se tekee mahdottomaksi? Tiedostamisen vaatimus sisältää siis yleistettävyyden periaatteen. Paikastaan tietoisen tutkijan teksti ei siis näyttäydy vinoutuneena yleistyksenä, vaan osittaisena näkökulmana kysyttyyn asiaan.

\section{Hanna Ojala}

